\title{
Can meaningful work really moderate the relationship between supervisor support, coworker support and work Engagement?
}

\author{
Umair Ahmed $^{a^{*}}$, Abdul Halim Abdul Majid ${ }^{b}$, La aleh Al-Aali $^{a}$ and Soleman Mozammel ${ }^{a}$
}

${ }^{a}$ Arab Open university, Bahrain

${ }^{b}$ Universiti Utara Malaysia, Malaysia

\section{CH R O N I C L E}

Article history:

Received: October 19, 2018

Received in revised format: November 26, 2018

Accepted: November 29, 2018

Available online:

November 29, 2018

Keywords:

Work Engagement

Supervisor Support

Coworker Support

Meaningful work

Moderation

\begin{abstract}
Work engagement has gained much prominence over the recent decades. With the aim of addressing the global engagement crisis, the current study examined how prominent job resources such as supervisor support, coworker support and meaningful work perceptions can influence work engagement. The study also tested the moderation of meaningful work on these relationships. 537 questionnaires were distributed among the employees of six large banks of Pakistan. Structural equation modeling using Smart PLS 2.0 resulted in strong positive relationship of supervisor support and coworker support with work engagement. The findings also concluded strong positive relationship between meaningful work and work engagement. Notably, the bootstrapping results also played significant moderation of meaningful work on the relationship between supervisor support and coworker support with work engagement. The study forwards theoretical and practical implications for future.
\end{abstract}

\section{Introduction}

Growing competition in the business world has pushed organizations to think beyond conventional employee related prospects like motivation, commitment and satisfaction (Kuvaas, 2008; Rupert \& Smith, 2016). Today, organizations need employees with passion, energy, and dedication for their job roles. In other words, the corporate world needs employees with spark, energy, connectivity, and passion for their works, which in simple words, bring up the need for engaged work force. Work engagement is a psychological positive work based mindset, which enables an individual to work with high energy, pledge, vigor and absorption (Schaufeli et al., 2002; Crabtree, 2013). Work engagement brings proactive work behaviors, which leads towards several corporate benefits (Bakker \& Bal, 2010). Sadly, survey reports on engagement are not showcasing encouraging results (Gallup, 2013), outlining engagement levels as low as $13 \%$ on an average. For Pakistan, the statistics outline only $15 \%$ of the workforce on an average as work engaged. Notably, the service sector of the region of Asia has ranked the lowest, with 10\% engaged employees, only. Accordingly, the banking industry which holds the biggest share in the service sector of Pakistan has also been reported to have serious employees 'work engagement issues (SBP HR Developments, 2009; SBP Customer Service Practices, 2015). Likewise,

* Corresponding author.

E-mail address: umairahm@gmail.com (U. Ahmed) 
empirical studies have also recorded poor employee work behaviors in the banking sector. These alarming statistics are marked for urgent empirical attention. Markedly, research in this area has highlighted job resources such as supervisor support and coworker support have been termed as some of the most important predictors of work engagement (Bakker et al., 2007). Likewise, studies like Fairlie (2011) also prominently indicated towards the importance of meaningful work towards predicting work engagement. Keeping these evidences beforehand, the present study attempted to empirically test how supervisor support, coworker support, and meaningful work can help foster work engagement.

\section{Literature Review}

\subsection{Work Engagement}

Work engagement denotes to healthy state of mind that motivates an individual to bring high energy, commitment, and resilience at work (Bakker \& Leiter, 2010). Engaged workers are high in dedication and absorption due to which, the work becomes fun for them. Scholars have outlined that, work engaged individuals are better in performing compared with those who are not. Bakker and Leiter (2010) suggest that the growing competition and race for competitive edge these days require businesses to have work engaged people and are willing to go an extra mile for the businesses. Likewise, engaged workers are so much connected with their works that they outperform others through giving $21 \%$ higher performance and customer satisfaction at work (Bakker \& Bal, 2010). This is one of the major concerns of every other business in the current era, striving hard to bring in people with right work behaviors on job (Ahmed et al., 2016a,b).

\subsection{Job Resources}

Since its first conceptualization (Kahn, 1990), notable studies have outlined the significance of different jobs, individual and personal characteristics for work engagement prediction. Therein, job resources have been termed as some of the highly important for employee behaviors and outcomes in general (e.g. Imani et al., 2014) and engagement in particular (e.g., Ahmed et al., 2017). According to Bakker and Demerouti (2007), job resources are those job features that can help an individual work with more psychological resourcefulness thus, predicting work engagement. Conservation of resources theory (Hobfoll, 1989, 2001) has been regarded as the most appropriate underpinning theoretical explanation in this regard. According to the theory, individuals value resources as they help them enhance their behaviors and develop further resources. Keeping their prominence and imparity in view, the current study has attempted to investigate some of the notable job resources such as supervisor support, coworker support, and meaningful work and the relationship among the elements and work engagement.

\subsubsection{Supervisor support}

Supervisor support refers to an individual perception about the supervisor's support being significant and contributory towards the employees (Rhoades \& Eisenberger, 2002). In simple, supervisor support denotes to the extent to which an individual views his/her supervisor being supportive, handy and recognizing in major work prospects. Prominent empirical studies on the topic of work engagement have highlighted considerable importance of supervisor support (Bakker et al., 2007; Schaufeli \& Bakker, 2004). Studies have outlined that employees who receive healthy support from their supervisors are high in work engagement (Swanberg et al., 2011). Similarly, Morris et al. (2008) and James et al. (2011) also reported a strong correlation between supervisor support and work engagement. The findings have underlined that having supervisor support at the workplace is likely to help boost individual psychological wellness which thus, results in fostering work engagement. 
Consonant to this, longitudinal studies have also reported supervisor support to be strongly related with work engagement (Caesens et al., 2014; Hakanen et al., 2008). These studies have underscored that receiving supervisor support in the long run also help to keep the employees well engaged with their works. Notably, review of the past literature has outlined that literature pertaining to impact of supervisor support in enhancing work engagement is limited when it comes to emerging economies like Pakistan (Abbasi \& Alvi, 2012; Danish et al., 2014; Raja, 2012).

On the contrary, social support features at work have also been criticized for potential negative impact on individual wellbeing. The studies assert that at times, individuals view support features as unnecessary and hence result in affecting their confidence and self-esteem. Pertaining to work engagement, studies have also outlined insignificant or even negative role of supervisor support towards work engagement. For instance, Menguc et al. (2013) empirically found various results amongst employees pertaining to supervisor support and work engagement. Likewise, study by Poortvliet et al. (2015) outlined that employees come with different priorities and objectives hence, support from supervisor may not be equally appreciated by all hence, negatively affecting employees' work engagement. Similar empirical evidences were forwarded by Hengel et al. (2012) and Karatepe et al. (2010). According to Mozammel and Haan (2016), in a work environment, applying transformational leadership style does not assure that the employees will be fully engaged. Conclusively, these inconsistent findings directed for further empirical attention hence, the following hypothesis was tested:

\section{H1: There is a positive relationship between supervisor support and work engagement.}

\subsubsection{Coworker Support}

Coworker support is referred to support an employee from his/her peers at the workplace (Van Dierendonck et al., 1998). Coworker support plays a vital role in facilitating employees to perform well at work through boosting their psychological wellbeing. Work environment where employees receive adequate support from their coworkers can induce energy and dedication in employees as a result; they work with full immersion (Karatepe et al., 2010). Studies have outlined that coworker support develops a sense of belonging amongst the peers at work and active support in job related problems and friendly relationship can significantly boost work wellbeing (Anitha, 2014). Coworker support and facilitation during problems at work; appreciation on job related accomplishment, and maintenance of good working relationship can help boost energy, commitment, and immersion in work hence, fostering work engagement (Anitha, 2014; Hakanen et al., 2008; Caesens et al., 2014; Bakker et al., 2007; Schaufeli \& Bakker, 2004) outlined social support at work from coworkers as an important resource to predict work engagement. Parallel to supervisor support, studies have also reported insignificant and/or even negative impact of coworker support on work engagement. For example, a study by Freeney and Fellenz (2013) found no influence of coworker support on work engagement in the healthcare sector. Likewise, Bakker and Bal (2010) reported negative relationship between the two. Correspondingly, De Lange et al. (2008) also reported negative impact of coworker support on work engagement. These studies have concluded that support from coworkers at times hinders employees at work hence, negatively influencing their work wellness. Such a view is consonant with the idea that for some, social support from peers is not considered healthy as it makes them feel inferior at times. Keeping this in view, the current study realized the need for further empirical comprehension on the relationship hence, tested the following hypothesis:

H2: There is a positive relationship between coworker support and work engagement.

\subsubsection{Meaningful Work}

Meaningful work is judgment of an individual about the work being purposeful and important (Rosso et al., 2010). It is likely for an employee to experience the work being meaningful when it is clearly 
understandable; aligns their personal abilities and upholds the perception that the invested efforts will yield valuable contribution for oneself and organization at large (Steger et al., 2012). Based on the explanation of Conservation of Resources Theory (Hobfoll, 2001), meaningful work is also an important job resource (Fairlie, 2011) and can be have high significance on employees in different ways. For instance, popular literature on the consequences of meaningful work reported its momentous influence on employee behaviors such as job satisfaction (Steger et al., 2013), work motivation (Chalofsky \& Krishna, 2009), and organizational commitment (Steger et al., 2013).

However, on the contrary, very little is known concerning on meaningful work and its association with work engagement (Steger et al., 2013). Fairlie (2011) performed major work on this topic whereby, he empirically claimed that meaningful work plays a momentous role in enhancing work engagement and can also be of prominent significance when in further strengthening the connection of other job resources with work engagement. The author suggests that meaningful work is a sleeping giant with vital significance towards predicting work engagement yet still; it is rarely investigated. Therefore, taking the recommendations forward, the current study attempted to examine the potential direct influence of meaningful work perceptions on employees` work engagement with the following hypothesis:

\section{H3: There is a positive relationship between meaningful work and work engagement.}

\subsection{Moderation of Meaningful Work}

Baron and Kenny (1986) stated that moderating variable can be introduced when there is a weak or inconsistent relationship between the endogenous and exogenous variables. Notably, on theoretical grounds, Conservation of Resources (COR) theory (Hobfoll, 2001) also states that availability of additional resources can facilitate in furthering the role and impact of resources available. Following this explanation, Bakker et al. (2007) and Bakker (2011) outlined that several job resources can considerably buffer the impact of other job resources upon work engagement. In light of this argument, several studies can be traced (Xanthopoulou et al., 2013; Simpson, 2009) that examined and concluded positive moderation of several job factors and resources in this regard.

Importantly, several studies can be traced testing the moderating role of different variables to better understand employee outcomes (e.g., Shahverdi et al., 2018; Akinbola et al., 2018). Stinger and Broverie (2007) underlined the potential role of meaningful work towards enhancing work engagement and furthering job resources to strengthen their relationship with work wellbeing (engagement). Since meaningful work refers to situation whereby, individual perceive the assigned job and work roles to be worthy, significant, and contributory (Steger et al., 2012), one can understand its role in inducing a sense of positivity and connection, hence leading in maximization of available resources to showcase higher work engagement. Notably, this view is also in consonance with the conceptualization of work engagement by Kahn (1990); who first coined the term engagement and the notable role of meaningful work in this regard. Moreover, Steger et al. (2012) also empirically outlined the moderating capacity of meaningful work whereby, Fairlie (2011) also forwarded similar understanding. The moderation of meaningful work is yet to be empirically tested on these relationships whereby, Ahmed et al. (2016) also presented arguments and recommendations concerning the moderating potential of meaningful work on the relationship among supervisor support, coworker support and work engagement. Henceforth, the present study asserted that the relationship between supervisor support, coworker support and work engagement may also change as a result of perceptions about their work being meaningful. Therefore, following hypotheses were tested:

\section{H4: The relationship between supervisor support and work engagement is moderated by meaningful} work 


\subsection{Sampling}

Sample consisted of six large banks of Pakistan for the present study. Therein, Krejcie and Morgon (1970) table was used to ascertain the sample required for the 86,930 (Banking Survey, 2014-15) target employees of these banks. As per the table, 384 was the minimum sample required for the present study. Adding a further 40 percent of the total, the current study distributed 537 questionnaires for results and analysis. For the purpose of ease and convenience, proportionate stratified random sampling approach was deployed whereby; the sample was drawn into meaningful segments on the basis of their percentage of employees in each of the six banks. Table 1 elaborates further details in this aspect.

Table 1

Sample distribution

\begin{tabular}{|c|c|c|c|c|c|}
\hline S. No & Bank & No of Staff & $\begin{array}{l}\% \text { of Population } \\
\text { against the Total }\end{array}$ & $\begin{array}{l}\text { Required Questionnaire } \\
\text { from each bank }\end{array}$ & $\begin{array}{c}\text { Round Off } \\
\text { Total }\end{array}$ \\
\hline 1 & Habib Bank Limited (HBL) & 14,123 & 16.25 & 87.26 & 87 \\
\hline 2 & National Bank Limited (NBP) & 24,871 & 28.61 & 153.60 & 154 \\
\hline 3 & United Bank Limited (UBL) & 13,771 & 15.84 & 85.60 & 85 \\
\hline 4 & Muslim Commercial Bank (MCB) & 12,301 & 14.15 & 75.98 & 76 \\
\hline 5 & Allied Bank Limited (ABL) & 10,194 & 11.73 & 62.99 & 63 \\
\hline \multirow[t]{2}{*}{6} & Bank Alfalah Limited (BAF) & 11,670 & 13.42 & 72.06 & 72 \\
\hline & Total & 86,930 & 100 & 537 & 537 \\
\hline
\end{tabular}

\subsection{Measures}

Work engagement was assessed through 9-item scale by UWES (Schaufeli et al., 2006). It comprises of positively worded statements, asking individuals about the commitment, energy and absorption that they feel at work. Accordingly, supervisor support was assessed through 9-item scale by Van Veldhoven and Meijman (1994) and coworker support through 9-item scale by Van Veldhoven and Meijman (1994). 7-item scale by Ashmos and Duchon (2000) was deployed to assess meaningful work (e.g., "see Appendix A for questionnaire items"). All the scales were carefully selected from prominent literatures to ensure effective results. The respondents were made to answer through using five-point Likert scale.

\subsection{Demographic Profile of the Respondents}

Concerning to demographics outlines that majority of the respondents $(238 ; 85.9 \%)$ were male professionals working in the banking sector whereas, only 39 were women which mark for 14.1 percent of the total number of respondents. Importantly, 131 (47.3\%) of the total respondents reported to be between 31-40 years of age category whereby, $118(42.6 \%)$ reported to be from 30 years or below category. For education report suggests that $200(72.2 \%)$ had a master level academic qualification whereas, $71(25.6 \%)$ obtained a bachelor's degree. These demographics results are in line with some of the studies conducted in the banking sector previously. For instance, study on work stress and its impact on job performance in the banking sector of Pakistan reported 87 percent of the respondents to be male (Bashir \& Ismail Ramay, 2010). Similarly, another study examining employee performance in the banking sector of Pakistan reported 62.5 percent of its respondents as male and 60.4 percent having a master degree qualification (Shahid et al., 2011). Lastly for experience, a good 143 (51.6\%) respondents of the current study turned out to be having 0-5 years of experience leaving 91 (32.9\%) in 6-10 years; 28 $(10.1 \%)$ in $11-15$ years, and $15(5.4 \%)$ in the category of 11 years and above respectively.

\subsection{Analysis}

Structural equation modeling approach (Wold, 1974; 1985) was deployed through using Smart PLS 2.0 M3 software (Ringle et al., 2005). The PLS path modeling approach is referred as the most appropriate 
technique due to its robust relationship estimation and path analysis. Moreover, PLS uses multivariate analysis technique which has received high recognition in social and psychological research topics (Hair et al., 2013). The PLS path modeling approach runs through two stages known as Measurement model assessment and structural model assessment.

\subsection{Measurement Model Assessment}

This stage caters to the assessment of psychometric properties of the scales adapted in the study. Therein, the individual item reliability, internal consistency, and discriminant validity are ascertained. In order to assess the individual item reliability, the outer loadings (Hulland, 1999) of every item is examined for which, 0.50 has been termed as the minimum acceptable threshold.

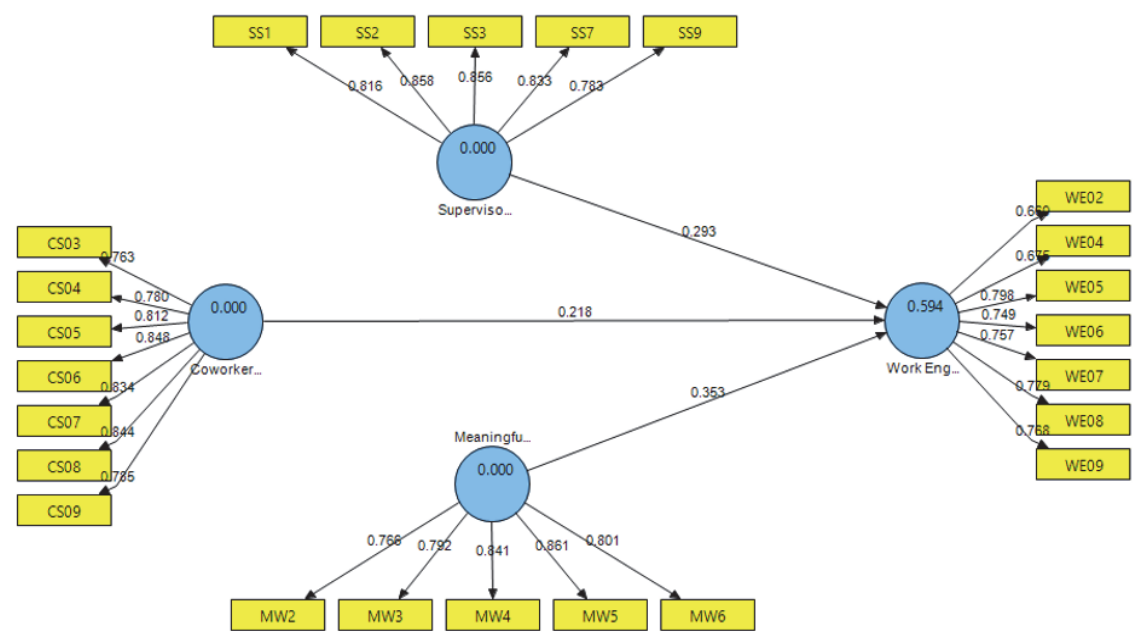

Table 2

Fig. 1. Measurement Model

Loadings, AVE and Composite Reliability Coefficients

\begin{tabular}{|c|c|c|c|c|c|}
\hline Construct & Items & Loadings & AVE & $\mathbf{C R}$ & $\mathbf{R 2}$ \\
\hline \multirow[t]{6}{*}{ Supervisor Support } & & & 0.688 & 0.916 & \\
\hline & SS01 & 0.815 & & & \\
\hline & SS02 & 0.858 & & & \\
\hline & SS03 & 0.856 & & & \\
\hline & SS07 & 0.832 & & & \\
\hline & SS09 & 0.782 & & & \\
\hline \multirow[t]{10}{*}{ Coworker Support } & & & 0.656 & 0.929 & \\
\hline & CS01 & 0.762 & & & \\
\hline & $\mathrm{CS} 02$ & 0.779 & & & \\
\hline & $\mathrm{CS} 03$ & 0.811 & & & \\
\hline & CS04 & 0.848 & & & \\
\hline & CS05 & 0.834 & & & \\
\hline & CS06 & 0.843 & & & \\
\hline & $\mathrm{CS} 07$ & 0.784 & & & \\
\hline & CS08 & 0.762 & & & \\
\hline & $\mathrm{CS} 09$ & 0.779 & & & \\
\hline \multirow[t]{6}{*}{ Meaningful Work } & & & 0.660 & 0.906 & \\
\hline & MW02 & 0.765 & & & \\
\hline & MW03 & 0.792 & & & \\
\hline & MW04 & 0.840 & & & \\
\hline & MW05 & 0.860 & & & \\
\hline & MW06 & 0.800 & & & \\
\hline \multirow[t]{8}{*}{ Work Engagement } & & & 0.551 & 0.895 & 0.594 \\
\hline & WE02 & 0.659 & & & \\
\hline & WE04 & 0.674 & & & \\
\hline & WE05 & 0.798 & & & \\
\hline & WE06 & 0.748 & & & \\
\hline & WE07 & 0.756 & & & \\
\hline & WE08 & 0.778 & & & \\
\hline & WE09 & 0.768 & & & \\
\hline
\end{tabular}


Following to this, 4 items from supervisor support; 2 items were from meaningful work, and 2 items from work engagement construct were deleted. Thus, 26 items were retained in the model for further analysis and assessment. Next, composite reliability coefficients were examined, keeping in view the rule of thumb suggested by Bagozzi and Yi (1988) and recommended by Hair et al. (2011). Notably, all the CR coefficient scores fell between 0.895 and 0.926 thus, confirming sufficient composite reliability. Table 2 provides further details in this regard. In parallel, discriminant validity was assessed through ascertaining average variance extracted (AVE) scores to be equal or above 0.50 for each item (Hair et al., 2010). In addition, the square root of AVE was also assessed in comparison with its correlating values for further confirmation of discriminant validity. Therein, Fornell and Larcker (1981) suggested that the square root values should be greater than the correlations amongst the latent variables. Results in Fig. 1 and Tables (2-3) suggest significant discriminant validity for all the latent constructs.

Table 3

Discriminant Validity

\begin{tabular}{ccccc}
\hline & CS & MW & SS & WE \\
\hline CS & $\mathbf{0 . 8 0 9}$ & & & \\
MW & 0.671 & $\mathbf{0 . 8 1 2}$ & & \\
SS & 0.776 & 0.643 & $\mathbf{0 . 8 2 9}$ & $\mathbf{0 . 7 4 2}$ \\
WE & 0.682 & 0.688 & 0.689 & \\
\hline
\end{tabular}

Note: Bold faced values are the square root results for each of the Latent constructs.

\subsection{Structural Model Assessment}

Upon the affirmation of psychometric results, the assessment of path coefficients was carried out to outline the strength of relationship between the endogenous and exogenous variables. For this, 500 bootstraps (Hair et al., 2012) were applied on 277 sample cases to examine the direct relationship at the first instance (Hair et al., 2014; Hair et al., 2012; Hair et al., 2009).

Results of the path modeling outlined positive relationship between supervisor support and work engagement $(\beta=0.293, t=4.18)$. The findings are in agreement with the empirical results of Swanberg et al. (2011), Morris et al. (2008), and James et al. (2011), suggesting that help and support from the immediate supervisor; their appreciation towards work efforts; recognition, and work facilitation can significantly help employees boost their psychological connectivities; hence predicting work engagement. In specific, the finding highlights that respondents (bankers) perceived their supervisors to be recognized helpful, and handy which led them boost their psychological resourcefulness and predicted work engagement. Accordingly, hypothesis 2 was formulated to test the relationship and influence of coworker support upon employees` work engagement. The PLS path modeling results have outlined that employees perceived their coworkers to be supportive, handy, and recognizing which in turn, significantly harnessed their work wellbeing to express work engagement. The structural model results have outlined a highly significant positive relationship between the two $(\beta=0.217, \mathrm{t}=2.90)$ henceforth, waiving support for hypothesis 2. The results are parallel to Anitha (2014); Bakker et al. (2007), and Caesens et al. (2014), highlighting significant influence of coworker support and facilitation on employees' work engagement. The results have outlined that respondents (bankers) valued coworker support and help, guidance and facilitation that they received as crucial to engage with their work. In parallel, meaningful work was also examined regarding its impact on work engagement under hypothesis 3. The statistical results have also confirmed support for this hypothesis, outlining positive influence of meaningful work upon work engagement $(\beta=0.353, t=7.48)$. The study has found highly significant relationship between meaningful work and work engagement thus, expressing full support towards the claims of Fairlie (2011). The finding underscores that when employees view their work as notable, contributory, and impactful, they tend to boost their association with the work and express high engagement. Pertaining to the respondents of the study, the results suggest that bankers viewed 
their work being meaningful and assigned roles as contributory. This resulted in enabling them to boost their work engagement. The finding thus educates that; employees with a sense of meaningfulness about their work would give their best to work with high dedication, vigor, and energy, in other words work engagement. Fig. 2 and Table 3 provide further details in this regard.

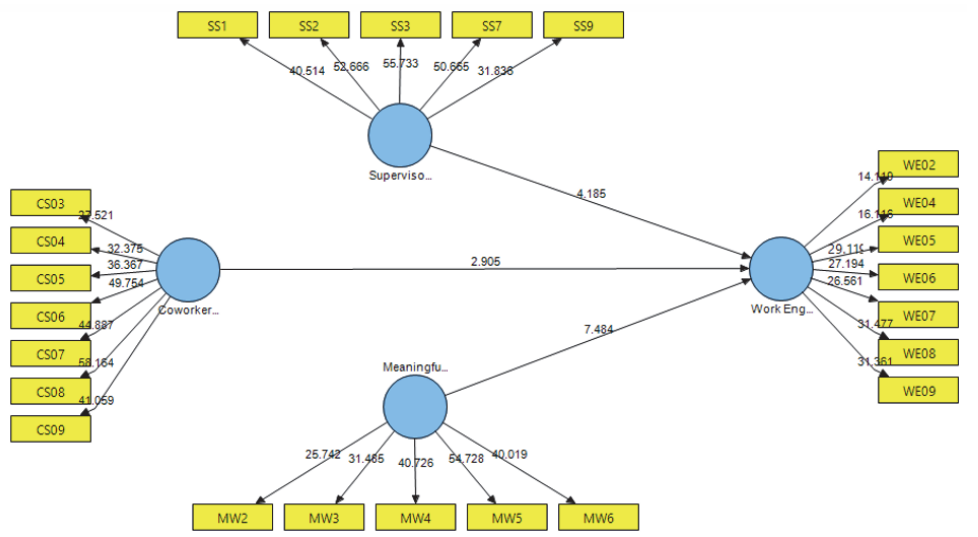

Fig. 2. Structural Model- Direct Results

Table 4

Hypothesis Testing- Direct Results

\begin{tabular}{cccccc}
\hline Relationship & Beta & Std Error & t-value & P-Value & Decision \\
\hline SS $\rightarrow$ WE & 0.293 & 0.070 & 4.18 & 0.000 & Supported \\
CS $\rightarrow$ WE & 0.217 & 0.075 & 2.90 & 0.000 & Supported \\
MW $\rightarrow$ WE & 0.353 & 0.047 & 7.48 & 0.000 & Supported \\
\hline
\end{tabular}

\subsection{Test of Moderation}

Concerning to the moderation, hypothesis 4 was formulated to examine the moderating role of meaningful work on the relationship between supervisor support and work engagement. Bootstrapping procedures were applied using PLS path modeling approach which reported significant moderation of meaningful work $(\beta=0.179, \mathrm{t}=2.41)$, hence supporting hypothesis 4 . The results have landed support for the recommendations of Ahmed et al. (2016) and Fairlie (2011), suggesting that employees' perceptions about their work being meaningful can considerably help them capitalize upon the available resources like supervisor support to further strengthen their work engagement. In other words, employees viewing their work as meaningful can be more resourceful and hence capable of making the most of available support, guidance, and acknowledgement from immediate supervisors to enrich their work engagement. Accordingly, hypothesis 5 pertained for testing the moderating role of meaningful work on the relationship between coworker support and work engagement. The results showcased in Fig. 3 and Table 4 have also outlined significant moderation of meaningful work on this relationship $(\beta=0.150, t=1.74)$ hence, offering support for hypothesis 5 as well. The result refers that meaningful work perceptions can interact and facilitate employees to maximize upon support from their coworkers in a much more effective manner and further their work engagement. The finding has forwarded empirical support towards the notion that creating a meaningful work environment whereby, people view their jobs as notable and contributory will enthusiastically get employees to make the best use of available support resources to demonstrate higher work engagement.

Table 5

Hypothesis Testing- Moderation Results

\begin{tabular}{cccccc}
\hline Relationship & Beta & Std Error & t-value & P-Value & Decision \\
\hline SS $\times$ MW & 0.179 & 0.074 & 2.41 & 0.000 & Supported \\
CS $\times$ MW & 0.150 & 0.086 & 1.74 & 0.000 & Supported \\
\hline
\end{tabular}




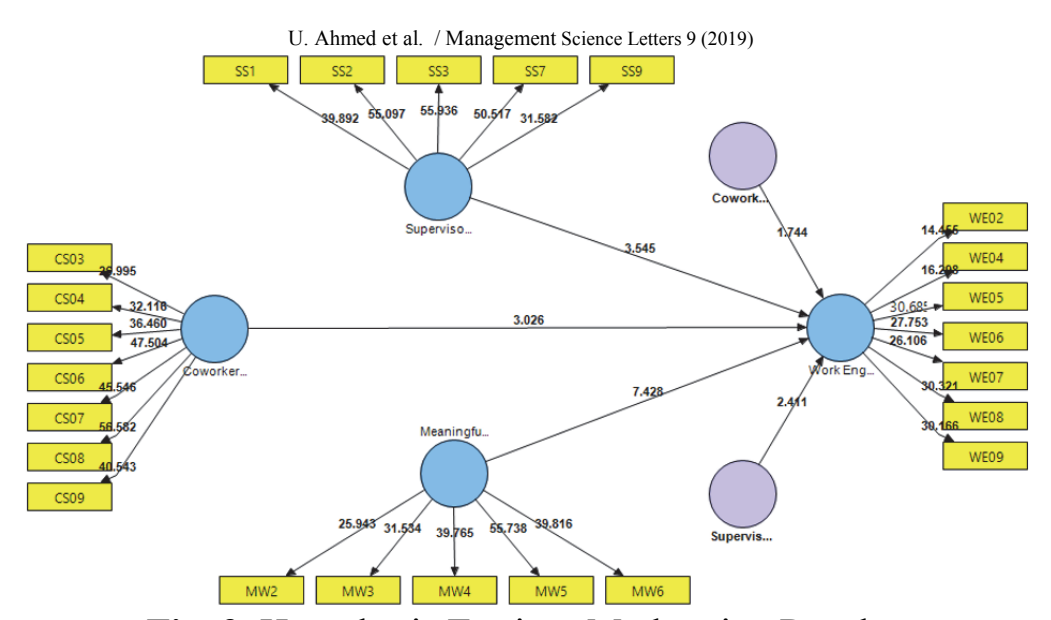

Fig. 3. Hypothesis Testing- Moderation Results

\section{Discussion}

The core aim of the present study was to test how notable job resources including supervisor support, coworker support and meaningful work influence on employees' work engagement. Therein, the study also aimed to respond towards the inconsistent results pertaining to these resources in connection with engagement. Accordingly, the study also strived to empirically explain how meaningful work perceptions can enrich the relationship of supervisor support, coworker support and work engagement across the large six banks of Pakistan. The results have outlined that supervisor support is a crucial resource to foster work engagement. As per the findings, employees who viewed supervisor support valuable, recognizing, and significant actually felt more psychologically capable at work and related it with their work engagement. The finding highlighted that supervisor help and expert facilitation are important for employees and therefore, enable them to bring the best of their energy, absorption, and commitment towards work; in other words, expressing work engagement. The current study has found that similar to the results from other demographics and occupational settings (Swanberg et al., 2011; Morris et al., 2008; James et al., 2011), supervisor support is also considered as vital by the bankers in Pakistan. The findings have outlined that regardless of demographics and occupational settings, supervisor guidance and support works the way up for everyone especially when it comes to harnessing engagement at work. In a way, it also pin points towards the prominence of supervisory authority and employees' faith and reliance in their help and support. Similarly, the respondents viewed coworkers to be of great value for their psychological resourcefulness. The finding has outlined that coworkers can make a tremendous impact when it comes to engaging employees at work. Analogous to Anitha (2014); Bakker et al., (2007), and Caesens et al. (2014), the present study has conveyed that coworkers' guidance; problem support; appreciation, and encouraging behaviors induce energy in employees. As a result, they become capable of working with a sense of high commitment and absorption towards assigned tasks; in other words, expressing work engagement. Equally, the study found individual perceptions about their work being valuable and significant to be of considerable importance towards harnessing work engagement. The findings have concluded that when employees view their work to be contributory for the organization and valuable for their career and broader life goals; it invokes a motivational process which leads them to give their best at work. Hence, meaningful work perceptions are significant to predict work engagement. Viewing the work as joyful, interesting and connected with personal outlay towards career and life can help employees develop a wider sense of understanding with the job hence boosting their engagement. As a consequence, this meaningfulness facilitates them in bringing psychological availability towards work. This result is also consistent with the explanations of Kahn (1990) who, while first conceptualizing the concept of engagement quoted that, employees need to experience meaningfulness in their work to boost engagement. In addition, positive perceptions about meaningful work also resulted to be significantly moderating the role and impact of supervisor support and coworker support towards work engagement. This suggests that capitalization of such support resources at work can be best enhanced through making employees view that they are provided with meaningful work (Fairlie, 
2011). The finding has strengthened the theoretical explanations of Conservation of Resources Theory (Hobfoll, 2001), outlining how additional resources like meaningful work perceptions can energize to capitalize upon other available resources for profound employees' behaviors and outcomes at work. The finding in a way can be simplified for understanding with an example that, when an employee views the assigned role and responsibility to be of value, contributory for organization and significant, the motivation towards capitalizing upon available resource prospects like supervisor and coworker support would ultimately be higher for enhancing behaviors like work engagement.

\subsection{Implications for Research}

The implications of the study are multifold. At first, the present study suggests that job resources like supervisor support, coworker support and meaningful work are important prospects to predict work engagement. In addition, the present study has outlined meaningful work as an important arena for research scholars in the area of work engagement, particularly for the maximization of available resources to predict work engagement. Based on this, several avenues for further research could be underscored. For instance, one prospect would be to investigate other individual, job and/or organizational resources and how meaningful work possibly moderates their relationships with work engagement. Accordingly, whilst furthering the explanations of Fairlie (2011) and Kahn (1990), pertaining to the importance of meaningful work, future scholars may also consider exploring how global work engagement crisis could be responsively addressed through meaningful work. Accordingly, since there is no one size fits all, finding when it comes to work engagement (Steger et al., 2013), there is a potential to examine how employees in other occupational settings view these support resources and meaningfulness of work. Meaningful work is one of the core requirements of individuals from the respective organizations (Asik-Dizdar \& Esen, 2016) and therefore, its effective fulfillment can undoubtedly act as a gigantic work engagement booster. Furthermore, scholars may also consider fleshing out how supervisor support and coworker support can be of value for other sectors to help their employees make the most of these support resources to boost their psychological wellbeing at work. In addition, future researchers may also consider testing how meaningful work can facilitate engagement prospects over the long run both, directly as well as in the capacity of a moderator. This will also aid value in terms of paucity of longitudinal studies in the area of work engagement. Likewise, since meaningful work is an individual cognitive and motivational variable (Steger et al., 2013), one can understand higher probability of its buffering impact on the relationship of personal resources like Self-efficacy, resilience, and Self-esteem (Xanthopoulou et al., 2007) with work engagement. Henceforward, future scholars may also consider testing its moderating potential on such variables for better empirical and theoretical comprehension.

\subsection{Implications for practice}

Some practical implications can also be forwarded from the present study. At first, job resources like supervisor support has resulted to be significantly important for work engagement enhancement. Based on the results, the current study implies organizations to help employees in the supervisory positions to understand their role and contribution when it comes to engaging employees for better performance and profound work behaviors. Training programs can be of great value to help develop responsive supervisory skills in this regard. Likewise, top management and supervisory position holders can also attempt to mentor subordinates pertaining to how they can help support each other and foster work engagement. Equally, the strong positive impact of coworker support on employees' work engagement highlights the prominence of peer group, peer support, and group chemistry amongst the employees in Pakistani banks. Enterprises may need to work on mentoring and educating employees about how they can psychologically enable each other through support, guidance, facilitation, appreciation, and trouble shooting. In parallel, organizations are implied to play their part in enabling employees to view their work as meaningful. Job design (Rousseau, 1977) and job crafting (Asik-Dizdar \& Esen, 2016; Berg et al., 2013) approaches can be tremendous to help employees view their work as meaningful and hence, 
induce work engagement. The current study has outlined meaningful work as an essential variable to predict work engagement. In today's increasingly competitive work environments, employees demand to understand what they are responsible for and how it serves specific targets or objectives (Asik-Dizdar \& Esen, 2016). Managers can play an essential role in this regard through offering individualized attention to understand employees' priorities and perceptions about the work in order to figure how they can possibly view assigned role and responsibilities significant, contributory, and worthwhile; in other words, meaningful. Therein, managers need to understand that engagement is a long-term process and so the meaningful work. Therefore, it may possibly require a continuous effort to help individuals on job associate meaning with their work and hence, result in capitalization of other available resources like supervisor support and coworker support to predict work engagement.

\subsection{Limitations of the Study}

The present study is accompanied with some important limitations. Firstly, the current study deployed cross section approach with self-reporting measures for data collection. This, as a consequence, limits the causality of the findings. Despite the fact that, the findings are in line with work engagement literatures (Demerouti et al., 2001) and Conservation of Resources Theory (Hobfoll, 1989; 2001), it is possible that employees in other occupational setting and demographics may view these job resources differently. Similarly, the importance and understanding regarding meaningfulness of work may also be different because of culture differences (Steger et al., 2013). Hence, studies in other cultural context may also be considered for better generalizability of the results. Accordingly, since the present study sampled from homogeneous employees from one sector (banking) in Pakistan; future studies are therefore encouraged to consider examining multiple business sectors for effective comparative results and better comprehension of factors pertaining to work engagement.

\section{Conclusion}

To conclude, the current study has attempted to address major theoretical and empirical gaps in the area of work engagement. The study has outlined that for lower engagement levels in the banking employees of Pakistan, job resources including supervisor support, coworker support and meaningful work can be of considerable value. The study has concluded that employees valued supervisor support, coworker support, and meaningful work in connection to their work engagement. Moreover, the study also found significant moderation of meaningful work on the relationship of supervisor support and coworker support with work engagement. Taken together, the study has concluded that through integrating different job resources, organizational scholars can be in a better position to understand work engagement and its prediction.

\section{References}

Akinbola, O., Solomon, K., \& Ibidunni, S. (2018). Moderating influence of corporate social responsibility on organizational performance of brewing transnational corporation. International Journal of Data and Network Science, 2(2), 49-56.

Ahmed, U., Majid, A.H.A., \& Zin, M.L.M. (2016a). Moderation of meaningful work on the relationship of supervisor support and coworker support with work engagement. East Asian Journal of Business Management, 6(3), 15-20.

Ahmed, U., Majid, A. H. A., \& Zin, M. L. M. (2016b). Meaningful work and work engagement: A relationship demanding urgent attention. International Journal of Academic Research in Business and Social Sciences, 6(8), 116-122.

Ahmed, U., Umrani, W. A., Pahi, M. H., \& Shah, S. M. M. (2017). Engaging PhD students: Investigating the role of supervisor support and psychological capital in a mediated model. Iranian Journal of Management Studies, 10(2), 283-306.

Abbasi, A. S., \& Alvi, A. K. (2012). Impact of organizational justice on employee engagement in Banking sector of Pakistan. Middle-East. Journal of Scientific Research, 12(5), 643-649. 
Asik-Dizdar, O., \& Esen, A. (2016). Sensemaking at work: meaningful work experience for individuals and organizations. International Journal of Organizational Analysis, 24(1), 2-17.

Anitha, J. (2014). Determinants of employee engagement and their impact on employee performance. International Journal of Productivity and Performance Management, 63(3), 308-323.

Ashmos, D. P., \& Duchon, D. (2000). Spirituality at work: A conceptualization and measure. Journal of Management Inquiry, 9(2), 134-145.

Bagozzi, R. P., \& Yi, Y. (1988). On the evaluation of structural equation models. Journal of the Academy of Marketing Science, 16(1), 74-94.

Bakker, A. B., Hakanen, J. J., Demerouti, E., \& Xanthopoulou, D. (2007). Job resources boost work engagement, particularly when job demands are high. Journal of Educational Psychology, 99(2), 274-284.

Bakker, A. B., \& Demerouti, E. (2007). The job demands-resources model: State of the art. Journal of Managerial Psychology, 22(3), 309-328.

Bakker, A. B., \& Demerouti, E. (2008). Towards a model of work engagement. Career Development International, 13(3), 209-223.

Bakker, A. B., \& Leiter, M. P. (2010). Work engagement: A handbook of essential theory and research. New York: Psychology Press.

Bakker, A. B., \& Bal, M. P. (2010). Weekly work engagement and performance: A study among starting teachers. Journal of Occupational and Organizational Psychology, 83(1), 189-206.

Baron, R. M., \& Kenny, D. A. (1986). The moderator-mediator variable distinction in social psychological research: Conceptual, strategic, and statistical considerations. Journal of personality and social psychology, 51(6), 1173.

Bashir, U., \& Ismail Ramay, M. (2010). Impact of stress on employees job performance: A study on banking sector of Pakistan. International Journal of Marketing Studies, 2(1), 122-126.

Berg, J. M., Dutton, J. E., \& Wrzesniewski, A. (2013). Job crafting and meaningful work. In B. J. Dik, Z. S. Byrne \& M. F. Steger (Eds.), Purpose and meaning in the workplace (pp. 81-104). Washington, DC.

Caesens, G., Stinglhamber, F., \& Luypaert, G. (2014). The impact of work engagement and workaholism on well-being: The role of work-related social support. Career Development International, 19(7), 813835.

Chalofsky, N., \& Krishna, V. (2009). Meaningfulness, commitment, and engagement: The intersection of a deeper level of intrinsic motivation. Advances in Developing Human Resources, 11(2), 189-203.

Crabtree, S. (2013). Worldwide, 13\% of employees are engaged at work. The Gallup Incorporation. Available at http://www.gallup.com/poll/165269/worldwide-employees-engaged-work.aspx

Danish, R. Q., Ahmad, F., \& Khan, M. A. (2014). Determinants of Employee Engagement in Service Sector of Pakistan. Universal Journal of Management, 2(2), 64-71.

Demerouti, E., Bakker, A. B., Nachreiner, F., \& Schaufeli, W. B. (2001). The job demands-resources model of burnout. Journal of Applied Psychology, 86(3), 499-512.

De Lange, A. H., De Witte, H., \& Notelaers, G. (2008). Should I stay or should I go? Examining longitudinal relations among job resources and work engagement for stayers versus movers. Work \& Stress, 22(3), 201-223.

Fairlie, P. (2011). Meaningful Work, Employee Engagement, and Other Key Employee Outcomes: Implications for Human Resource Development. Advances in Developing Human Resources, 13(4), 508-525.

Fornell, C., \& Larcker, D. F. (1981). Evaluating structural equation models with unobservable variables and measurement error. Journal of Marketing Research, 18(1), 39-50.

Freeney, Y., \& Fellenz, M. R. (2013). Work engagement, job design and the role of the social context at work: Exploring antecedents from a relational perspective. Human Relations, 66(11), 1427-1445.

Gallup (2013). Worldwide, 13\% of employees are engaged at work. The Gallup Incorporation. Available at http://www.gallup.com/poll/165269/worldwide-employees-engaged-work.aspx

Hair, J. F., Ringle, C. M., \& Sarstedt, M. (2011). PLS-SEM: Indeed a silver bullet. Journal of Marketing Theory and Practice, 19(2), 139-152.

Hair, J. F., Ringle, C. M., \& Sarstedt, M. (2013). Editorial-partial least squares structural equation modeling: Rigorous applications, better results and higher acceptance. Long Range Planning, 46(2013), 1-12.

Hair, J. F., Anderson, R. E., Babin, B. J., \& Black, W. C. (2010). Multivariate data analysis: A global perspective (Vol. 7). NJ: Pearson Upper Saddle River. 
Hair, J. F., Sarstedt, M., Ringle, C. M., \& Mena, J. A. (2012). An assessment of the use of partial least squares structural equation modeling in marketing research. Journal of the Academy of Marketing Science, 40(3), 414-433.

Hakanen, J. J., Schaufeli, W. B., \& Ahola, K. (2008). The Job Demands-Resources model: A three-year cross-lagged study of burnout, depression, commitment, and work engagement. Work \& Stress, 22(3), 224-241.

Hengel, K. M. O., Blatter, B. M., Geuskens, G. A., Koppes, L. L., \& Bongers, P. M. (2012). Factors associated with the ability and willingness to continue working until the age of 65 in construction workers. International archives of occupational and environmental health, 85(7), 783-790.

Hobfoll, S. E. (1989). Conservation of resources: A new attempt at conceptualizing stress. American Psychologist, 44(3), 513-524.

Hobfoll, S. E. (2001). The influence of culture, community, and the nested-self in the stress process: advancing conservation of resources theory. Applied Psychology, 50(3), 337-421.

Hulland, J. (1999). Use of partial least squares (PLS) in strategic management research: A review of four recent studies. Strategic Management Journal, 20(2), 195-204.

Imani, J., Beygi, R., Gholiopour, A., \& Farhangi, A. (2014). The role of television in institutionalization of human resources principles in Iranian general policies of administrative system. Management Science Letters, 4(3), 447-458.

James, J. B., McKechnie, S., \& Swanberg, J. (2011). Predicting employee engagement in an age-diverse retail workforce. Journal of Organizational Behavior, 32(2), 173-196.

Kahn, W. A. (1990). Psychological conditions of personal engagement and disengagement at work. Academy of Management Journal, 33(4), 692-724.

Karatepe, O. M., Keshavarz, S., \& Nejati, S. (2010). Do core self-evaluations mediate the effect of coworker support on work engagement? A study of hotel employees in Iran. Journal of Hospitality and Tourism Management, 17(1), 62-71.

Krejcie, R. V., \& Morgan, D. W. (1970). Determining sample size for research activities. Educational and Psychological Measurement, 30(3), 607-610.

Kuvaas, B. (2008). An exploration of how the employee-organization relationship affects the linkage between perception of developmental human resource practices and employee outcomes. Journal of Management Studies, 45(1), 1-25.

Morris, M. W., Podolny, J., \& Sullivan, B. N. (2008). Culture and coworker relations: Interpersonal patterns in American, Chinese, German, and Spanish divisions of a global retail bank. Organization Science, 19(4), 517-532.

Mozammel, S., \& Haan, P. (2016). Transformational leadership and employee engagement in the banking sector in Bangladesh. The Journal of Developing Areas, 50(6), 43-55.

Poortvliet, P. M., Anseel, F., \& Theuwis, F. (2015). Mastery-approach and mastery-avoidance goals and their relation with exhaustion and engagement at work: The roles of emotional and instrumental support. Work \& Stress, 29(2), 150-170.

Raja, M. W. (2012). Does transformational leadership leads to higher employee work engagement. A study of Pakistani service sector firms. International Journal of Academic Research in Business and Social Sciences, 2(1), 160-166.

Rhoades, L., \& Eisenberger, R. (2002). Perceived organizational support: a review of the literature. Journal of Applied Psychology, 87(4), 698-714.

Ringle, C. M., Wende, S., \& Will, S. (2005). SmartPLS 2.0 beta. University of Hamburg, Germany. Retrieved from:https://www.smartpls.com/\#downloads

Rosso, B. D., Dekas, K. H., \& Wrzesniewski, A. (2010). On the meaning of work: A theoretical integration and review. Research in Organizational Behavior, 30, 91-127.

Rothmann, S., \& Buys, C. (2011). Job demands and resources, psychological conditions, religious coping and work engagement of reformed church ministers. Journal of Psychology in Africa, 21(2), 173-183.

Rousseau, D. M. (1977). Technological differences in job characteristics, employee satisfaction, and motivation: A synthesis of job design research and sociotechnical systems theory. Organizational Behavior and Human Performance, 19(1), 18-42.

Rupert, M., \& Smith, H. (2016). Historical Materialism and Globalisation: Essays on Continuity and Change: London: Routledge. 
Schaufeli, W. B., \& Bakker, A. B. (2004). Job demands, job resources, and their relationship with burnout and engagement: A multi-sample study. Journal of Organizational Behavior, 25(3), 293-315.

Schaufeli, W. B., Bakker, A. B., \& Salanova, M. (2006). The measurement of work engagement with a short questionnaire a cross-national study. Educational and Psychological Measurement, 66(4), 701716.

Schaufeli, W. B., Salanova, M., González-Romá, V., \& Bakker, A. B. (2002). The measurement of engagement and burnout: A two sample confirmatory factor analytic approach. Journal of Happiness Studies, 3(1), 71-92.

Shahid, M. N., Latif, K., Sohail, N., \& Ashraf, M. A. (2012). Work stress and employee performance in banking sector evidence from district Faisalabad, Pakistan. Asian Journal of Business and Management Sciences, 1(7), 38-47.

Shahverdi, M., Ismail, K., \& Qureshi, M. (2018). The effect of perceived barriers on social entrepreneurship intention in Malaysian universities: The moderating role of education. Management Science Letters, 8(5), 341-352.

Simpson, M. R. (2009). Predictors of work engagement among medical-surgical registered nurses. Western Journal of Nursing Research, 31(1), 44-65.

State Bank of Pakistan. (2009). HR Developments (pp. 73-80). State Bank of Pakistan. Available at http://www.gilanifoundation.com/homepage/Free Pub/SBP/Annual Report 2008-2009 Vol-II.pdf

State Bank of Pakistan CSR (2014, July 12). Diagnostic review of the consumer service practices in banking sector of Pakistan, State Bank of Pakistan. Retrieved from: http://www.sbp.org.pk/cpd/dr.pdf

State Bank of Pakistan. (2009). HR Developments (pp. 73-80). State Bank of Pakistan. Retrieved from: http://www.gilanifoundation.com/homepage/Free_Pub/SBP/Annual_Report_2008-2009_Vol-II.pdf

Steger, M. F., \& Dik, B. J. (2009). If one is looking for meaning in life, does it help to find meaning in work?. Applied Psychology: Health and Well-Being, 1(3), 303-320.

Steger, M. F., Dik, B. J., \& Duffy, R. D. (2012). Measuring meaningful work: The work and meaning inventory (WAMI). Journal of Career Assessment, 20(3), 322-337.

Steger, M. F., Littman-Ovadia, H., Miller, M., Menger, L., \& Rothmann, S. (2013). Engaging in work even when it is meaningless: Positive affective disposition and meaningful work interact in relation to work engagement. Journal of Career Assessment, 21(2), 348-361.

Stinger, C., Boverie, P. (2007). The role of meaning in work: A study of the transformational power of Meaningful work. Paper presented at the 7th International Transformative Learning Conference New Mexico. Transformative Learning: Issues of Difference and Diversity, (2007), 305-309

Swanberg, J. E., McKechnie, S. P., Ojha, M. U., \& James, J. B. (2011). Schedule control, supervisor support and work engagement: A winning combination for workers in hourly jobs? Journal of Vocational Behavior, 79(3), 613-624.

Van Veldhoven, M., \& Meijman, T. (1994). Het meten van Psychosociale arbeidsbelasting. [The measurement of psychosocial job demands]. Amsterdam: Nederlands Instituut voor Arbeidsomstandigheden.

Van Dierendonck, D., Schaufeli, W. B., \& Buunk, B. P. (1998). The evaluation of an individual burnout intervention program: The role of inequity and social support. Journal of Applied Psychology, 83(3), 392-407.

Veldhoven, M. v., Jonge, J. d., Broersen, S., Kompier, M., \& Meijman, T. (2002). Specific relationships between psychosocial job conditions and job-related stress: A three-level analytic approach. Work \& Stress, 16(3), 207-228.

Wold, H. (1974). Causal flows with latent variables: Partings of the ways in the light of NIPALS modelling. European Economic Review, 5(1), 67-86.

Wold, H. (1985). Partial least squares. In S. Kotz \& N. L. Johnson (Eds.), Encyclopedia of statistical sciences (Vol. 6, pp. 581-591). New York, NY: Wiley \& Sons.

Xanthopoulou, D., Bakker, A. B., \& Fischbach, A. (2013). Work engagement among employees facing emotional demands: The role of personal resources. Journal of Personnel Psychology, 12(2), 74.

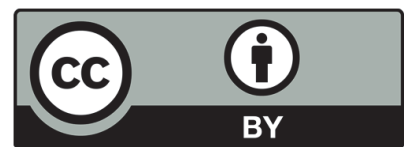

(C) 2019 by the authors; licensee Growing Science, Canada. This is an open access article distributed under the terms and conditions of the Creative Commons Attribution (CC-BY) license (http://creativecommons.org/licenses/by/4.0/). 